\title{
Penguatan BUMDes (Badan Usaha Milik Desa) dengan Memaksimalkan Pemanfaatan Berbagai Fasilitas Digital
}

\author{
Muhammad Ridwansyah ${ }^{1}$, Dwi Hastuti ${ }^{2 *}$, Heriberta $^{3}$, Syaparuddin $^{4}$, Emilia $^{5}$ \\ 1,2,3,4,5) Prodi Ekonomi Pembangunan Fakultas Ekonomi dan Bisnis Universitas Jambi
}

Diterima: 10-11-2021

Direvisi: $15-12-2021$

Disetujui: $18-12-2021$

Dipublikasi: 31-12-2021

\begin{abstract}
One of the national development goals is to achieve village independence, which requires the development of village potential, community social potential, and natural resource potential, all of which are both actors and objects in development. Furthermore, in order to achieve independence, BUMDes must be optimized. However, it was revealed that many villages lack the knowledge and resources to establish and optimize BUMDes. The problems that frequently occur related to its management, specifically: 1) the lack of community engagement in managing BUMDes, 2) the government has not been empowering the community optimally to establish BUMDes, and 3) the management of BUMDes is not running well. According to Law No. 6 of 2014, BUMDes is a business entity that receives the majority of its funds from communities through direct investment. The goal of optimizing BUMDes is to improve community services by empowering villages to be productive to boost their independence and strengthen the economy of rural communities. In particular, optimizing BUMDes with the use of digital facilities will encourage agritourism and agribusiness at the same time.
\end{abstract}

Keywords: BUMDes, natural resource, community economic

\begin{abstract}
Abstrak
Mewujudkan kemandirian desa merupakan salah satu tujuan pembangunan nasional dan diperlukan potensi desa, potensi sosial masyarakat, dan potensi sumber daya alam yang merupakan pelaku sekaligus objek dalam pembangunan. Selain itu, dalam mewujudkan kemandirian diperlukan optimalisasi Badan Usaha Milik Desa (BUMDes). Akan tetapi, kenyataan saat ini memperlihatkan bahwa banyak desa yang tidak tahu cara mendirikan dan mengoptimalkan BUMDes itu sendiri. Tantangan yang sering muncul terkait dengan pengelolaan BUMDes, yaitu 1) kurangnya partisipasi dari masyarakat dalam mengelola BUMDes, 2) pemerintah tidak optimal dalam memberdayakan masyarakat dalam pengembangan BUMDes, dan 3) pengelolaan dan manajemen BUMDes tidak berjalan. Berdasarkan UU No. 6 Tahun 2014, BUMDes merupakan badan usaha yang mayoritas dananya berasal dari desa dengan penyertaan langsung. Tujuan dari optimalisasi BUMDes yaitu untuk meningkatkan pelayanan kepada masyarakat dengan pemberdayaan desa dengan usaha-usaha produktif yang dikembangkan untuk meningkatkan kemandirian dan penguatan ekonomi masyarakat desa. Secara khusus, optimalisasi BUMDes dengan pemanfaatan fasilitas digital akan mendorong agrowisata dan agrobisnis secara bersamaan.
\end{abstract}

Kata kunci: BUMDes, sumber daya alam, ekonomi masyarakat

\section{Pendahuluan}

Perekonomian pedesaan sampai saat ini masih terdapat kendala yang serius karena adanya ketidakmampuan sumberdaya dalam mengoptimalkan potensi desanya. Permasalahan yang seringkali terjadi, misalnya kemiskinan, keterpurukan, ketertinggalan dan adanya diskriminasi yang terkait dengan pertumbuhan dan perkembangan masyarakat pedesaan.

\footnotetext{
*Penulis korespondensi

Email: dwihastuti@unja.ac.id
} 
Pertumbuhan masyarakat pedesaan erat kaitannya dengan peningkatan ekonomi di pedesaan (Dewi, 2010; Kinasih, dkk., 2020; Samsir, 2017). Oleh karena itu, untuk mencapai pertumbuhan ekonomi dan mengurangi kemiskinan maka diperlukan pendekatan baru yang dikenal dengan BUMDES (Junaidi, 2018).

BUMDes lahir sebagai pendekatan baru dalam meningkatkan ekonomi desa yang berdasarkan pada kebutuhan dan potensi lokal yang dimiliki masing-masing daerah. Reformasi tahun 1998 menjadi awal munculnya BUMDes dan diperkuat dengan UU No. 22 Tahun 1999 tentang pemerintah daerah yang bertujuan untuk mengembangkan desa-desa yang memiliki potensi yang dapat dikembangka (Rauf, 2019). Oleh karena itu, Rauf (2019) menyatakan bahwa BUMDes saat ini menjadi indikator dalam meningkatkan ekonomi masyarakat desa. Selanjutnya muncul peraturan baru tentang Desa terkait dengan BUMDes pada UU No. 32 Tahun 2004 yang mana desa memiliki dana hibah cukup besar yang diberikan oleh pemerintah pusat untuk mengoptimalkan potensi masing-masing daerah. BUMDes dapat meningkatkan lokakarya dan meningkatkan kemandirian ekonomi dan kesejahteraan masyarakat (Kinasih, dkk., 2020). Hal ini sejalan dengan pernyataan Junaidi (2018) yang mengatakan bahwa keberadaan BUMDes dapat meningkatkan pendapatan dan memperkuat ekonomi di masyarakat.

Tantangan BUMDes saat ini yaitu masih rendahnya kinerja dalam pembangunan ekonomi dan terlihat dari banyaknya kekurangan dalam proses pelaksanaannya serta basis unit usaha yang belum optimal (Kinasih, dkk., 2020). Selain itu, permasalahan produktivitas masyarakat yang rendah dengan minimnya produk olahan dan usaha yang dilakukan menjadikan peran BUMDes tidak fokus pada masyarakat. Tantangan lainnya yaitu ancaman organisasi yang memiliki ciri khas tersendiri dalam melakukan kegiatan usaha (Feriady, 2019). Menurut Dewi (2010), tantangan terkait dengan pembentukan BUMDes dapat diatasi dengan cara melakukan revisi pada peraturan daerah yang belum tepat sebagai Perda payungnya, kemudian memperbaiki bentuk badan hukumnya sesuai dengan badan hukum BUMDes sebagai badan hukum yang tepat.

Upaya yang dilakukan untuk mengatasi persoalan BUMDes saat ini yaitu dengan meningkatkan produktivitas masyarakat desa dan pembukuan dana dalam pengelolaan desa yang berpedoman pada aturan yang ditetapkan oleh pemerintah (Febryani, dkk., 2019). Kemudian, untuk optimalisasi kinerja BUMDes, diperlukan kepercayaan masyarakat dan keterlibatan masyarakat mengoptimalkan keunggulan atau potensi desa. Untuk membuat penyusunan potensi desa maka diperlukan bakat dan potensi masyarakat, organisasi warga, dan lembaga lokal dalam mendukung pengembangan potensi. Oleh karena itu, desa harus mengambil peran makro untuk menyelesaikan permasalahan pada level mikro (Samsir, 2017).

Selain itu, peran serta ibu-ibu PKK dalam meningkatkan usaha mikro UMKM akan sangat membantu bagi kelangsungan BUMDes. Kemudian dengan adanya peningkatan kapasitas dan manajemen serta pengembangan jaringan desa sangat mempengaruhi penguatan dan optimalisasi BUMDes (Srirejeki, dkk., 2020). BUMDes juga dapat menampung seluruh komponen potensi daerah yang kemudian dikelola dan dikembangkan menjadi produk unggulan berbasis potensi lokal dalam pembangunan ekonomi masyarakat (Chikmawati, 2019). Mendorong ekonomi masyarakat dapat dilakukan dengan memperluas ruang gerak dengan penguatan kelompok masyarakat dalam pengembangan usaha berdasarkan potensinya sebagai alternatif keberlanjutan program (Handoko, 2017). Keberhasilan pengelolaan BUMDes yang optimal dan efisien dapat memberikan dampak yang positif bagi perekonomian dan akhirnya kesejahteraan masyarakat akan meningkat (Febryani, dkk., 2019). Kesejahteraan merupakan tujuan utama berbagai aspek ekonomi. Ketika keberhasilan ekonomi di tingkat daerah mengalami peningkatan maka juga akan sejalan dengan peningkatan perekonomian secara nasional (Junaidi, 2018). 
BUMDes dapat mendorong dan mengembangkan potensi desa serta dapat mengatasi permasalahan yang terjadi (Samsir, 2017). Unit usaha yang dikembangkan oleh BUMDes, yaitu usaha simpan pinjam, perdagangan, dan agroindustri. Berdasarkan penjelasan di atas, maka pendekatan BUMDes dapat secara umum mengatasi permasalahan Desa Renah Alai saat ini. Hal ini diperkuat dengan pernyataan bahwa keberadaan BUMDes akan meningkatkan kreativitas, inovasi, dan variasi usaha BUMDes dengan potensi lokal desa (Rahayuningsih, dkk., 2019) dan keberadaan BUMDES menjadi indikator penguatan ekonomi desa (Andriani, 2017). Keberadaan BUMDes juga sangat penting untuk meningkatkan kesejahteraan masyarakat desa. Oleh karena itu, diperlukan pemberdayaan masyarakat dalam penguatan ekonomi desa termasuk sumber-sumber dana dalam meningkatkan pendapatan desa, dan pemenuhan kebutuhan desa melalui BUMDes secara mandiri dengan unit-unit usaha (Berutu, dkk., 2019). Sejalan dengan Asmaranto, dkk. (2020), pengembangan BUMDes dan keberadaannya semakin diperhitungkan karena desa memiliki potensi di bidang pertanian, perkebunan, dan peternakan. Potensi produk lokal semakin tinggi dan sejalan dengan kearifan lokal Desa Renah Alai Kecamatan Jangkat. Selain potensi produk, Desa Renah Alai juga memiliki potensi besar di bidang pariwisata. Namun sampai saat ini, potensi wisata belum secara optimal diberdayakan. Dengan demikian, peningkatan BUMDes sangat dipengaruhi oleh potensi produk olahan lokal dan pengembangan desa wisata (Rahayuningsih, dkk., 2019).

Secara khusus, pengabdian ini bertujuan untuk memperkuat BUMDes dan memaksimalkan pemanfaatan fasilitas digital di era teknologi dewasa ini. Jika dilihat dari kaca mata stakeholder, BUMDes terdiri dari empat aspek, yaitu aspek ekonomi, ekologi, sosial, dan kelembagaan (Pujiana, dkk., 2019). Implementasi program BUMDes sangat berkaitan dengan program pemberdayaan masyarakat yang bertujuan untuk menciptakan pertumbuhan ekonomi rakyat dan pemerataan kesejahteraan dengan pengembangan usaha kecil masyarakat dalam meningkatkan pendapatan masyarakat (Pujiana, dkk., 2019).

Selain itu, berdasarkan pengabdian kelompok yang dilakukan pada tahun 2020, beberapa tim pengabdian telah melakukan pelatihan terkait dengan diversifikasi produk lokal Desa Renah Alai, yaitu 1) pembuatan stick ubi dari ubi jalar, 2) pembuatan keripik kentang dari kentang, dan 3) sirup kayu manis dari kulit kayu manis. Pelatihan-pelatihan tersebut diharapkan memunculkan sentra UMKM atau usaha mikro baru di masyarakat. Akan tetapi, kendala yang dihadapi adalah terbatasnya infrastruktur Desa Renah Alai seperti sinyal yang kemudian menghambat digitalisasi. Sementara itu, manajemen pengelolaan secara digital sangat efisien dan mudah jika dikembangkan di masa pandemi Covid-19 saat ini.

Pengabdian Desa Renah Alai yang dilaksanakan pada tahun 2021 merupakan kelanjutan dari pengabdian di tahun 2020. Pengabdian dilakukan secara berkelompok oleh dosen dari Prodi Ekonomi Pembangunan Universitas Jambi. Dalam kegiatan ini, dilakukan pelatihan dan pemberdayaan masyarakat di berbagai aspek untuk meningkatkan agrobisnis dan agrowisata di Desa Renah Alai yang memiliki potensi wisata dan sumber daya alam yang besar (Parmadi, dkk., 2019). Desa Renah Alai memiliki sentra produksi pertanian yang cukup banyak seperti kopi, jagung, padi, singkong atau ubi jalar, kentang, stroberi, sayuran, kayu manis, dll. Selain itu, daerah ini berada di lokasi yang strategis dekat dengan Lembah Masurai, sehingga terdapat dua wisata di desa ini yaitu air terjun dan tracking ke Lembah Masurai. Selain itu, menurut Amzar, dkk., (2019), pembentukan jasa dan pengembangan usaha yang diinisasi keinginan kelompok masyarakat sangat penting untuk mendukung UMKM di Desa Renah Alai sebagai desa binaan.

Berdasarkan perjalanan proses pengabdian tersebut, tahun 2021 dilanjutkan pengabdian terkait dengan "Penguatan BUMDes (Badan Usaha Milik Desa) dengan memaksimalkan pemanfaatan berbagai fasilitas digital". 


\section{Rumusan masalah}

Kemandirian suatu desa merupakan cita-cita pembangunan nasional (Nursetiawan, 2018). Dalam membangun kemandirian desa terdapat 3 (tiga) fokus utama, yaitu 1) potensi desa, 2) potensi sosial, dan 3) potensi sumber daya manusia (SDM) (Nursetiawan, 2018). Untuk mewujudkan kemandirian desa, harus mampu mengoptimalkan BUMDes. Menurut Nursetiawan (2018) dan Anggraeni (2016), beberapa masalah yang seringkali muncul dalam pengelolaan BUMDes, yaitu 1) kurangnya partisipasi dari masyarakat dalam mengelola BUMDes, 2) pemerintah tidak optimal dalam memberdayakan masyarakat dalam pengembangan BUMDes, dan 3) pengelolaan dan manajemen BUMDes tidak berjalan. Keberadaan BUMDes sangat penting karena dapat mengurangi pengangguran dan meningkatkan kesejahteraan masyarakat (Anggraeni, 2016; Darwita \& Redana, 2018). Oleh karena itu BUMDES merupakan salah satu alternatif dalam meningkatkan ekonomi pedesaan (Dewi, 2010).

Di lain pihak, BUMDes menjadi salah satu alternatif dalam meningkatkan ekonomi pedesaan (Darwita \& Redana, 2018). Oleh karena itu, perlu strategi untuk membenahi Perda payungnya dan membenahi bentuk badan hukum BUMDes (Dewi, 2010). Selan itu, juga diperlukan stabilisator, innovator, moderator, pelopor, dan pelaksana dalam memberdayakan masyarakat agar dapat berjalan dengan baik (Darwita \& Redana, 2018). Kerja sama pemerintah untuk menyelaraskan program pemerintah dengan BUMDes agar memperkuat tujuan dan mempercepat pertumbuhan ekonomi desa juga diperlukan (Bambang, 2017).

Pelaksanaan PkM Tahun 2020 lebih fokus pada promosi pembangunan lembaga BUMDes yang bertujuan untuk meningkatkan kesejahteraan masyarakat dan mengurangi kemiskinan. Sesuai dengan MoU antara Desa Renah Alai dan Prodi Ekonomi Pembangunan UNJA, desa ini telah menjadi desa mitra hampir tiga tahun. Dengan demikian, pelaksanaan di tahun 2021 ini merupakan yang kegiatan yang ketiga kali. Secara khusus, PkM ini dilaksanakan untuk menjawab persoalan terkait optimalisasi BUMDes dengan pemanfaatan fasilitas digital yang akan mendorong agrowisata dan agrobisnis secara bersamaan.

\section{Solusi permasalahan mitra}

Adanya potensi agrowisata dan agrobisnis membuat Desa Renah Alai berpotensi untuk dikembangkan menjadi desa wisata. Di sisi agrowisata, desa ini memiliki banyak hasil pertanian dan perkebunan, serta wisata yang asri. Hal ini menarik wisatawan dari luar daerah untuk berkunjung ke Desa Renah Alai untuk menikmati pemandangan Lembah Masurai, dan pertanian serta perkebunan di desa ini. Sementara itu, dari segi agribisnis, terlihat beberapa sumber daya alam seperti ubi jalar, kayu manis, dan kentang yang telah diolah oleh masyarakat desa sebagai produk dengan nilai tambah. Nilai tambah yang dihasilkan oleh produk olahan ini sejalan dengan tingginya nilai ekonomis suatu produk yang mana petani dapat menjual makanan olahan dengan harga yang lebih tinggi. Selain itu produk tidak mudah rusak karena daya tahan produknya cukup lama.

Jika usaha-usaha kreatif masyarakat sudah tumbuh dan mampu mengoptimalkan BUMDes, Desa Renah Alai dapat menjadi desa yang mandiri. Meskipun tidak mudah untuk membuat usaha menjadi sangat produktif dan masyarakat menjadi aktif, hal ini lah yang kemudian menjadi tantangan untuk kepala desa dan jajarannya. Kemudian, mereka harus melakukan sinergitas dengan pemerintah kecamatan dan kabupaten untuk terus menggalakkan kebersamaan dalam membangun desa. Selain itu, partisipasi swasta juga diperlukan untuk memberikan tambahan dana pada beberapa kerja sama dan program yang saling berkaitan. Tantangan di Desa Renah Alai saat ini adalah kesulitan sinyal telekomunikasi di beberapa tempat. Tim pengabdian mencoba untuk menjalin kerja sama dengan pihak swasta dan pemerintah untuk pembangunan tower sehingga permasalahan dapat teratasi secepatnya. Dengan potensi yang sudah cukup optimal, maka penguatan BUMDes menjadi target utama pengabdian dengan memanfaatkan fasilitas digital yang dimiliki oleh 
masyarakat Desa Renah Alai Kecamatan Jangkat Kabupaten Merangin. Sejalan dengan pengabdian tersebut maka pemerintah desa harus menyiapkan sarana dan prasarana yang mendukung pelaksanaan agar dapat berjalan dengan lancar.

Pelaksanaan pengabdian dilakukan sekitar bulan Juli atau Agustus 2021 di Kantor Desa Renah Alai dengan melibatkan masyarakat yang terlibat dalam pembekalan BUMDes dengan menerapkan fasilitas digital. Masyarakat yang ikut serta adalah yang memiliki pengetahuan terkait BUMDes dan mampu mengoperasikan handphone dan laptop. Hal ini dilakukan agar penyampaian materi dapat langsung dipahami secara baik dan intensif oleh masyarakat. Pengabdian pada masyarakat skema pelaksana PPM 2021 Prodi Ekonomi Pembangunan Desa Renah Alai merupakan wujud konsistensi sesuai dengan perjanjian desa mitra dengan Nomor 107/UN21.5.3/KS/2020 dan Nomor 141.1/026/KDRA/2020.

\section{Metode Pengabdian}

Terdapat beberapa metode yang dilakukan pada penyuluhan, yaitu partisipatif, demonstrasi, dan praktek untuk mempermudah pencapaian tujuan pengabdian (Satrya, dkk., 2019). Selain itu, terdapat beberapa metode secara keseluruhan yang hampir sama, yaitu 1) pembangunan komunitas masyarakat yang kreatif dan inovatif, 2) persuasi atau ajakan kepada masyarakat, 3) pemberdayaan dan pelatihan kepada masyarakat, 4) sinergitas masyarakat, dan 5) potensi dan budaya lokal. Tahapan-tahapan tersebut secara lebih detail dapat dilihat pada Gambar 1.

\section{Penguatan komunitas}

-Pengembangan kualitas SDM masyarakat

- Pemberdayaan usaha-usaha kreatif dan potensial dalam strategi optimalisasi dana BUMDes

- Peningkatan pertumbuhan ekonomi dengan terus mengemabngakan potensi BUMDes berbasis digital

2.Persuasi berupa ajakan kepada masyarakat

- Mengajak masayrakat untuk mengemabgkan potensi desa dengan produk dan wisata potensial

- Meningkatkan strategi promosi dangan memanfaatkan fasilitas digital dan yang ada

- Optimalsisasi BUMDes dengan pemberdayaan masyarakat yang terus dilakukan pelatihan sumber daya

\section{Pemberdayaan dan pelatihan masyarakat}

- Pendekatan program BUMDes dan potensi sumber daya produk lokal

- Optimalisasi program dengan potensi wisata air terjun dan tracing lembah Masurai sebagai daya tarik wisata

-Keserasisan pembanguan dengan cita-cita dan harapan pemerintah dan masyarakat

\section{Sinergi dengan masyarakat}

- Kerjasama masyarakat dengan berbagai instansi dalam pembangunan berkelanjutan dan berwawasan lingkungan

- Jaringan kerjasama yang luas antara masyarakat, pemerintah dan swasta akan meningkatkan pembangunan sesuai dengan keselarasan program kerjanya

\section{Potensi dan budaya lokal}

- Optimalisasi agrobisnis dan agrowisata Desa Renah Alai dengan basis kearifan lokal masyarakat

- Memberdayakan potensi masyarakat sesuai dengan tradisi yang dimilikinya

Gambar 1. Tahapan Pelaksanaan Kegiatan Pengabdian (PkM)

\section{Pelaksanaan pengabdian}

Sejalan dengan metode yang digunakan dalam pengabdian, maka pada tahun 2021 dilakukan dua tahapan. Tahap awal atau pertama terdiri dari: 1) Survey lokasi pengabdian 
yang akan menjadi desa mitra ; 2) Menanyakan potensi desa yang dimiliki; 3) Survey potensi desa dan review dari hasil pengabdian dua tahun terakhir; dan 4) Keinginan masyarakat akan pengabdian tahun 2021 oleh perguruan tinggi khususnya Prodi Ekonomi Pembangunan UNJA.

Tahap review terkait dengan evaluasi pengabdian yang dilaksanakan di tahun-tahun sebelumnya dan melihat kendala yang dihadapi oleh masyarakat. Melalui metode diskusi bersama mitra, diketahui bahwa pemahaman dan kompetensi warga telah meningkat dan hanya diperlukan peningkatan motivasi sehingga pelatihan dapat diterapkan secara berkelanjutan.

Tahap ke-2 pada pelaksanaan PkM tahun 2021 dengan tahapan-tahapan sebagai berikut: 1) Survey pelaksanaan $\mathrm{PkM}$ periode 2021; 2) Konsultasi mitra terkait teknis pelaksanaan pengabdian; 3) Alokasi waktu pengabdian dan jumlah peserta yang hadir; 4) Konfirmasi mahasiswa; 5) Perizinan turun ke lapangan dari FEB dan LPPM; dan 5) Monitoring selama kegiatan berlangsung.

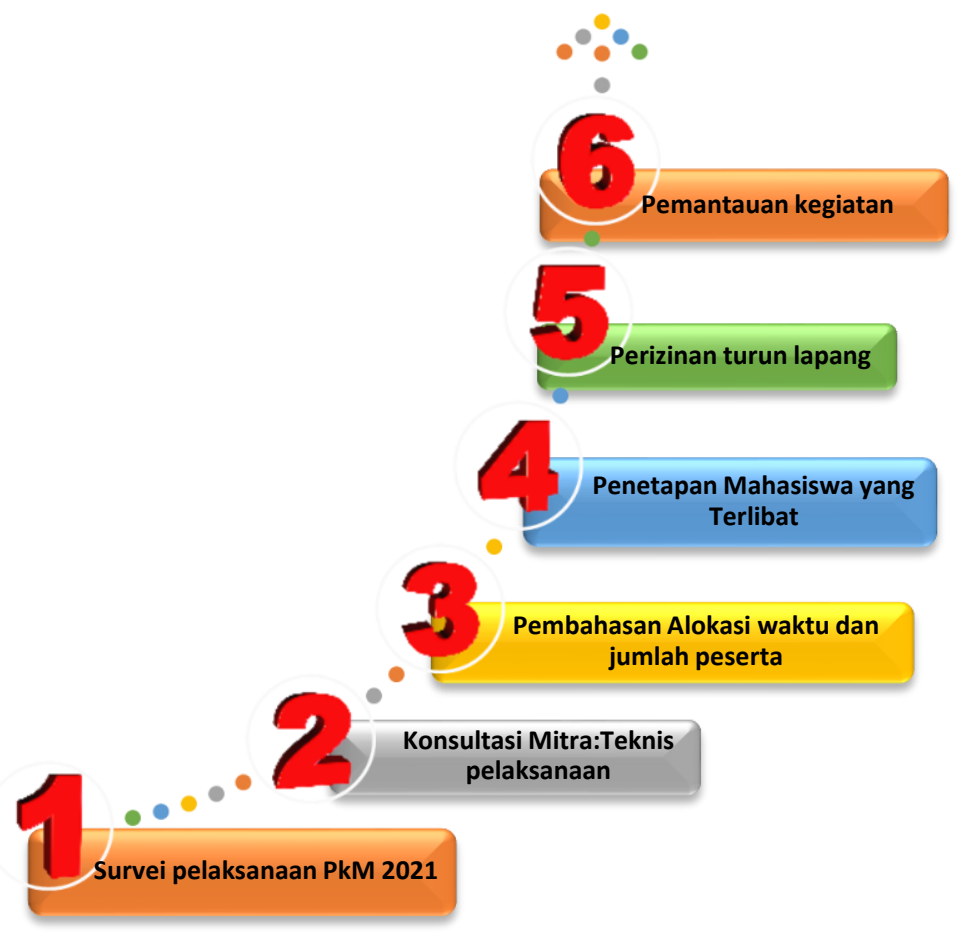

Gambar 2. Tahapan-tahapan pelaksanaan PkM

Target yang ingin dicapai pada kegiatan pengabdian kepada masyarakat Prodi Ekonomi Pembangunan Tahun 2021, yakni

1) Pemberdayaan, pelatihan, dan pembekalan berkelanjutan sejak tahun 2019 diharapkan dapat diimplementasikan oleh masyarakat Desa Renah Alai dalam rangka peningkatan kreativitas dan strategi pembangunan

2) Peningkatan pendapatan masyarakat Desa Renah Alai secara menyeluruh dengan optimalisasi produk lokal dan penguatan manajeman BUMDes yang dapat mengembangkan dan mendukung peningkatan ekonomi.

Sasaran peserta pelatihan adalah masyarakat yang telah menerima pelatihan BUMDes tahun 2019 dan memiliki kemampuan dalam mengoperasikan teknologi seperti handphone dan laptop. Pelaksanaan pengabdian ini merupakan wujud Tridarma sebagai dosen di PT yang dilakukan setiap tahunnya. Kegiatan ini mencoba memecahkan tantangan dan masalah dalam masyarakat, misalnya permasalahan BUMDes di Desa Renah Alai Kecamatan Jangkat Kabupaten Merangin. 
Tahap akhir dari pengabdian adalah tahap evaluasi yang dilakukan untuk melihat perkembangan BUMDes setelah dilakukan pembekalan dan pemberdayaan yang melibatkan tim pengabdian, instansi terkait dan pakar ahli. Hail akhir dimana BUMDes dapat diterapkan dan berkelanjutan. Jika selama dalam pelaksanaan mengalami masalah maka tim pengabdian melakukan revisi sehingga program pengabdian pada masyarakat tepat efektif, tepat guna, dan maksimal. Walaupun batas waktu pengabdian yang dilakukan telah selesai tetapi prodi EP FEB UNJA akan tetap melakukan pendampingan jika dibutuhkan dengan harapan komunikasi mitra tetap terjaga .

\section{Hasil dan Pembahasan}

\section{Hasil}

Perkembangan BUMDes sangat ditentukan bagaimana strategi yang dilakukan oleh pengelola atau pengurus BUMDes. Oleh karena itu perlunya dilakukan sinergi perangkat Desa Renah Alai beserta jajarannya untuk secara bersama-sama membangun BUMDes dengan pemanfaatan teknologi digital. Selain itu diperlukan kemampuan manajemen dengan memadukan serangkaian perubahan, baik yang berasal dari luar (pasar) maupun di dalam (organisasi) serta digitalisasi, yang menempatkan produk dan jasa BUMDes pada posisi yang mampu bersaing secara berkelanjutan dibandingkan dengan para pesaingnya.

Manajemen strategi sangat tepat dalam semua pengelola baik yang mencari keuntungan maupun organisasi non-profit (sosial), pemerintah maupun sektor swasta. Manajemen strategi BUMDes berkaitan dengan bagaimana memutuskan strategi dan perencanaan yang dapat diambil oleh pengelola BUMDes dan memberikan pengaruh bagi organisasi. Hal ini merupakan proses di mana pucuk pimpinan BUMDes menentukan arah dan kinerja organisasi jangka panjang dengan memastikan bahwa formulasinya sudah dilakukan dengan cermat, pelaksanaannya efektif, dan selalu melakukan evaluasi terus menerus.

\section{Pembahasan}

Manajemen strategi BUMDes berbasis digital sangat berkaitan dengan bagaimana memutuskan strategi dan perencanaan yang dapat diambil oleh pengelola BUMDes dan memberikan pengaruh bagi organisasi. Langkah-langkah kegiatan untuk solusi permasalahan adalah sebagai berikut:

1. Pengelola diberikan motivasi untuk mengelola organisasi yang efektif. Materimateri terkait motivasi internal dan organisasi diberikan oleh pemateri dengan konsep forum group discussion terkait permasalahan yang terjadi dan pemberian umpan balik.

2. Ceramah - presentasi, yaitu peserta diberi transfer pemahaman terkait penyusunan Analisis SWOT.

3. Pelatihan pengembangan inovasi dilaksanakan untuk meningkatkan berbagai macam potensi usaha yang dapat dilaksanakan oleh BUMDes.

Bimbingan teknis kepada pengelola BUMDes Maju Jaya ini bersifat integratif dan berkelanjutan. Pada tahap sebelumnya, telah diperkenalkan tata cara membuat rencana bisnis, sebagai salah satu keluaran hasil kegiatan. Pada tahap lanjutan ini, pengelola BUMDes diharapkan dapat melakukan analisis SWOT, dan mampu mengidentifikasi potensi pengembangan produk unggulan BUMDes. 


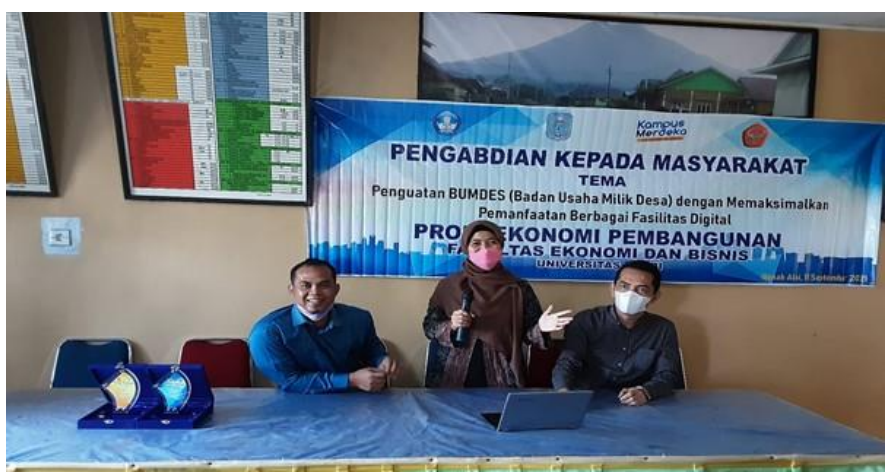

Gambar 3. Penyampaian materi terkait dengan BUMDes

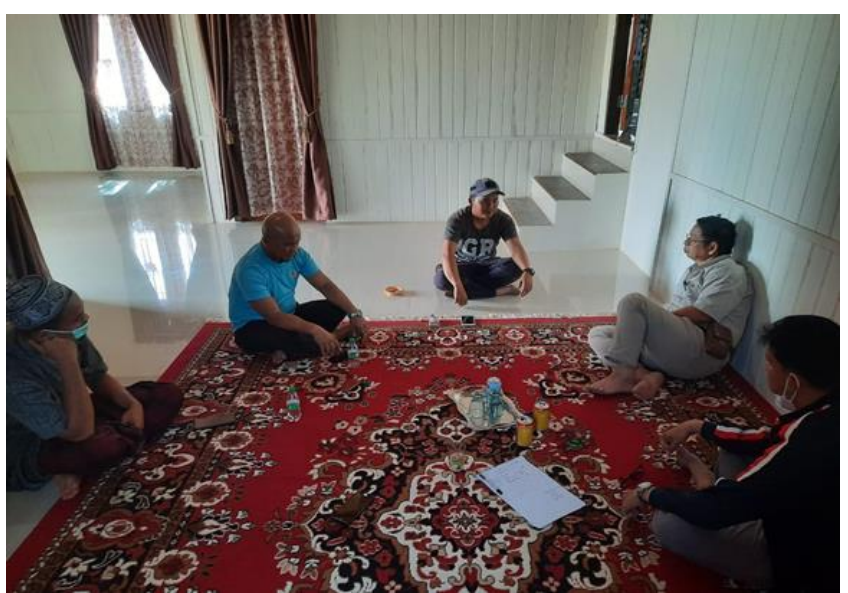

Gambar 4. Sosialisasi dengan Tim BUMDes

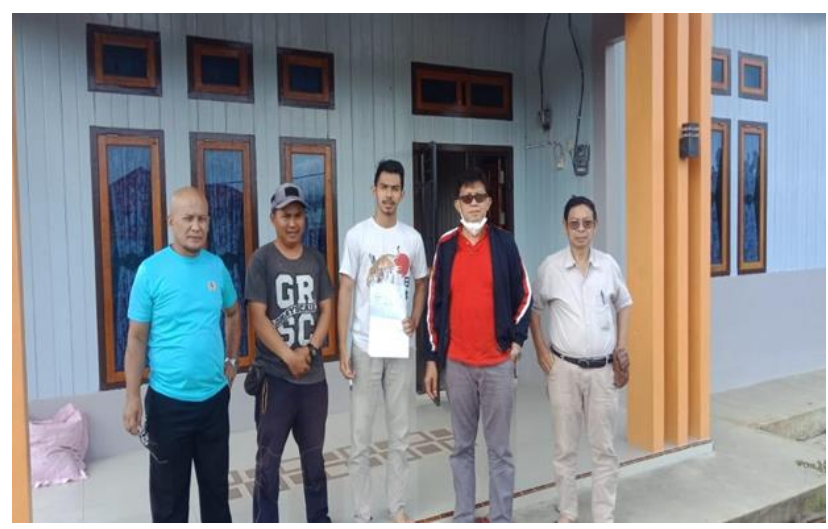

Gambar 5. Sosialisasi dengan Tim BUMDes

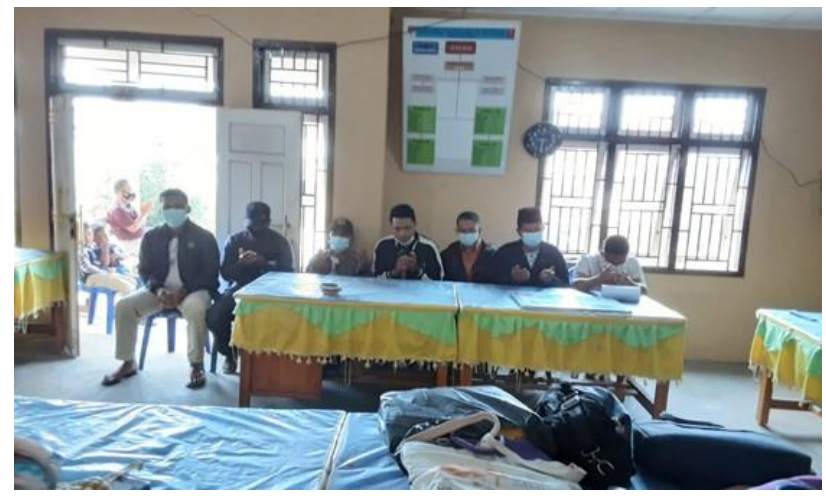

Gambar 6. Sosialisasi dengan masyarakat 


\section{Kesimpulan}

\section{Kesimpulan dan Saran}

1. Kawasan Desa Renah Alai yang berada di Kecamatan Jangkat Kabupaten Merangin merupakan desa yang potensial untuk pengembangan BUMDes berbasis digital dengan mengoptimalkan potensi SDA dan SDM yang dapat meningkatkan kesejahteraan masyarakat.

2. Kegiatan pengabdian ini memberikan gambaran bahwa keberadaan homestay menjadi sangat penting untuk menopang ekowisata lokal dengan mengoptimalkan pemanfaatan tata kelola homestay dengan dilakukannya pengaturan pembukuan, dan pemasaran dengan promosi ke media sosial, dll.

3. Adanya mahasiswa/i yang KKN di Desa Renah Alai sebagai Desa Mitra dapat mengoptimalkan pengelolaan dan manajemen homestay di beberapa aspek.

4. Berdasarkan hasil monitoring di lapangan, kegiatan pengabdian ke desa seperti pada BUMDes ini seharusnya dilaksanakan secara rutin dan berkala, melihat respon dan tingkat kebutuhan yang baik dari masyarakat dan BUMDes. Rencana kegiatan pengabdian selanjutnya adalah mengadakan pelatihan strategi membangun brand awareness bagi BUMDes dan UMKM.

\section{Saran}

1. Perlunya bimbingan dari Dinas Kebudayaan dan Dinas Pariwisata terkait pengembangan homestay supaya memiliki pengetahuan dan lebih aplikatif dalam memperbaiki homestay sehingga dapat menarik minat pengunjung wisatawan lokal maupun luar.

2. Membangun kerjasama dengan beberapa kelompok masyarakat, instansi, dan tour agent sehingga terintegrasi dalam perbaikan dan penyediaan fasilitas pendukung seperti pasokan makanan, infrastruktur yang baik, modal pengembangan dan kemudahan jasa travel untuk mempermudah wisatawan menjangkau lokasi. Pembangunan tower sinyal untuk mempermudah akses komunikasi akan diperlukan karena sebelumnya Desa Renah Alai memiliki kendala sinyal yang menghambat pertumbuhan ekonomi masyarakat.

3. Untuk keberlanjutan program pengabdian kepada masyarakat Prodi EP Fakultas Ekonomi dan Bisnis Universitas Jambi, telah dilakukan kerja sama dengan menjadikan Desa Renah Alai sebagai desa binaan atau dampingan. Sehingga kedepannya diperkuat dengan peningkatan mutu pegawai dengan mempekerjakan masyarakat sekitar dalam membuka peluang kerja baru. Oleh karena itu, diharapkan dapat melakukan monitoring dan mengevaluasi perkembangan homestay sebagai pengembangan agrowisata yang telah dikemas di Desa Renah Alai, sehingga dapat terus dilakukan penyempurnaan tahun selanjutnya sebagai Desa Binaan Prodi Ekonomi Pembangunan Fakultas Ekonomi dan Bisnis serta fakultas lainnya di lingkungan Universitas Jambi.

\section{Daftar Pustaka}

Amzar, Y. V. et al. (2019) 'Inisiasi dan pendampingan jasa pengembangan usaha (JPU ) Berbasis kearifan lokal bagi UMKM di Desa Renah Alai Kecamatan Jangkat Kabupaten Merangin'.

Andriani, S. (2017) 'Pengaruh BUMDes terhadap pengembangan ekonomi desa di Kecamatan Perbaungan Kabupaten Serdang Bedagai', Skripsi. Fakultas Ekonomi Dan Bisnis. Universitas Sumatera Utara.

Asmaranto, R. et al. (2020) 'Penguatan wilayah binaan mandiri energi melalui peningkatan kapasitas mikrohidro di Daerah Terpencil', Jurnal Teknik Pengairan. doi: 10.21776/ub.pengairan.2020.011.01.03.

Bambang, B. (2017) 'Pemetaan arah kebijakan pengembangan badan usaha milik desa di Kecamatan Kaligondang Kabupaten Purbalingga', EcceS (Economics, Social, and Development Studies). doi: 10.24252/ecc.v4i2.4433.

Berutu, B. R., Nasution, M. A. and Kadir, A. (2019) 'Peran badan usaha milik desa 
(BUMDes) dalam pemberdayaan masyarakat Desa Mungkur Kecamatan Siempat Rube Kabupaten Pakpak Bharat', Strukturasi: Jurnal Ilmiah Magister Administrasi Publik. doi: 10.31289/strukturasi.v1i1.1.

Chikmawati, Z. (2019) 'Peran BUMDES dalam meningkatkan pertumbuhan ekonomi pedesaan melalui penguatan sumber daya manusia', Jurnal Istiqro. doi: 10.30739/istiqro.v5i1.345.

Darwita, I. K. and Redana, D. N. (2018) 'Peranan badan usaha milik desa (BUMDes) dalam pemberdayaan masyarakat dan penanggulangan pengangguran di Desa Tejakula Kecamatan Tejakula Kabupaten Buleleng', Locus Majalah Ilmiah FISIP.

Dewi, A. S. K. (2010) 'Alternatif Bentuk badan hukum yang tepat dalam pendirian badan usaha milik desa (BUMDes) sebagai Upaya Meningkatkan Pendapatan Asli Desa ( PADes )', Jurnal Pamator.

Febryani, H. et al. (2019) 'Keberadaan badan usaha milik desa (bumdes) sebagai penguatan ekonomi desa abiantuwung', Jurnal Ilmiah Akuntansi dan Humanika. doi: 10.23887/jinah.v8i1.19865.

Feriady, M. (2019) 'Business Strategic analysis lembaga keuangan mikro berbasis BUMDES (LKM-BUMDES) Dalam Penguatan Ekonomi Desa', Equilibria Pendidikan : Jurnal Ilmiah Pendidikan Ekonomi. doi: 10.26877/ep.v3i2.3258.

Handoko, W. (2017) 'Menjaga sustainabilitas pengembangan masyarakat pesisir kebumen : antara corak top-down, partisipatif dan inisiasi kelembagaan lokal', Sosiohumaniora. doi: 10.24198/sosiohumaniora.v19i3.10291.

Junaidi, M. A. (2018) 'Peran badan usaha milik desa (bumdes) dalam penguatan ekonomi di Desa Kedung Turi Kecamatan Taman Kabupaten Sidoarjo', UNAIR Article.

Kinasih, I., Widiyahseno, B. and Wahjuni DJ, E. (2020) 'Badan usaha milik desa (BUMDes) dalam memperkuat perekonomian masyarakat', Jurnal Administrasi Pemerintahan Desa. doi: 10.32669/villages.v1i1.11.

Maria Rosa Ratna Sri Anggraeni (2016) 'Peranan badan usaha milik desa (BUMDes) pada kesejahteraan masyarakat pedesaan studi pada BUMDes di Gunung Kidul, Yogyakarta', Modus.

Nursetiawan, I. (2018) 'Strategi Pengembangan desa mandiri melalui inovasi BUMDes', Jurnal Ilmiah Ilmu Pemerintahan.

Parmadi, Dwi Hastuti, Erfit, Rahma Nurjanah, F. Z. (2019) 'Pengolahan limbah organik rumah tangga di Desa Renah Alai Kabupaten Merangin', Jitdm), 1(1), pp. 43-50. Available at: https://www.online-journal.unja.ac.id/JITDM/article/view/8677.

Pujiana, T., Arianti, D. and Mutolib, A. (2019) 'persepsi stakeholder terhadap pengembangan badan usaha milik desa (bumdes) di sungai langka, Kecamatan Gedong Tataan Kabupaten Pesawaran', Mimbar Agribisnis: Jurnal Pemikiran Masyarakat Ilmiah Berwawasan Agribisnis. doi: 10.25157/ma.v5i2.1905.

Rahayuningsih, Y., Budiarto, S. and Isminingsih, S. (2019) 'Peran BUMDes dalam penguatan ekonomi desa sukaratu kabupaten serang, banten', Jurnal Kebijakan Pembangunan Daerah. doi: 10.37950/jkpd.v3i2.63.

Rauf, R. (2019) 'Pengelolaan dan pengembangan badan usaha milik desa', Junal Valuta.

Samsir, A. (2017) 'Studi komperatif model BUMDes di Kabupaten Bantaeng', Jurnal Ad'ministrare doi: 10.26858/ja.v3i2.2564.

Satrya, I. D. G., Kaihatu, T. S. and Pranata, L. (2019) 'Upaya Pembinaan masyarakat dalam rangka pengembangan desa ekowisata di Dusun Mendiro, Desa Panglungan, Kecamatan Wonosalam, Kabupaten Jombang', Jurnal Terapan Abdimas. doi: 10.25273/jta.v4i1.3826.

Srirejeki, K. et al. (2020) 'Pemetaan Potensi Desa untuk Penguatan badan usaha milik desa dengan pendekatan asset based community-driven development', Warta LPM. doi: 10.23917/warta.v23i1.8974.

(C) 2021 oleh penulis. Pemegang Lisensi JPM, Indonesia. Artikel ini merupakan artikel akses terbuka yang didistribusikan di bawah syarat dan ketentuan Lisensi Atribusi Creative Commons (CC BY-SA) 